\title{
The effectiveness of basil extract on the mildew saprolegnia within in vitro
}

\section{Shara Sasmita, Indah Anggraini Yusanti id", Sofian}

Fisheries Science Faculty of Fisheries and Marine, Universitas PGRI Palembang, Indonesia

"Corresponding author: san915@ums.ac.id

\begin{tabular}{|c|c|}
\hline Article In & \\
\hline Article $\mathrm{H}$ & story: \\
\hline Received & 03 October 2020 \\
\hline Revised & II November 2020 \\
\hline Accepted & 24 March 202I \\
\hline Published & 30 April 202I \\
\hline
\end{tabular}

Keywords:

Basil extract

Antifungal

Saprolegnia sp.

In vitro
Fish disease is a serious problem faced in the aquaculture business. One of the diseases that attack cultured fish is saprolegniasis caused by the fungus Saprolegnia $s p$. The use of chemical drugs tends to be environmentally unfriendly and has other negative effects on these fish and humans. For this reason, a safer alternative treatment is needed to control fish disease caused by the fungus Saprolegnia sp. One of the plants that have the potential to treat disease caused by the fungus Saprolegnia sp. is basil (Ocimum basilicum L). This research aims to determine the effectiveness of basil extract against the fungus Saprolegnia $s p$. in vitro. This research was conducted from May to June 2019. The research method used was a completely randomized design (CRD) with 5 treatment levels and 3 replications including $0 \mathrm{ppm}$ (control), $20 \mathrm{ppm}, 40 \mathrm{ppm}$, $60 \mathrm{ppm}$, and $80 \mathrm{ppm}$ treatments. The test parameter observed was the inhibition zone diameter. In this study, 200 grams of basil extract were produced with $16.67 \%$ yield, the conclusion is that basil extract with a concentration of $60 \mathrm{ppm}$ has the largest inhibition zone diameter of $22 \mathrm{~mm}$ in inhibiting the growth of the fungus Saprolegnia $s p$ in vitro compared to other ethanol extract concentrations of basil.

Copyright (C) 202I, Sasmita et al This is an open access article under the CC-BY-SA license

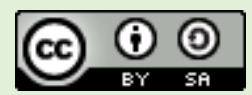

Citation: Sasmita, S., Yusanti I.A., \& Sofian. (202I). The effectiveness test of basil extract on the mildew saprolegnia within in vitro. JPBIO (Jurnal Pendidikan Biologi), 6(I), 76-83. DOI: https://doi.org/I0.31932/jpbio.v6iI.853

\section{INTRODUCTION}

The indicator of success in fish farming is the good health condition of the fish. If the health of the fish decreases, which is supported by poor environmental conditions, it will result in the emergence of disease in cultivated fish, which can cause losses to the cultivation business. One of the diseases in cultured fish is a mycotic disease that occurs due to fungal attack, the source of which can be derived from Saprolegnia $s p$ which causes saprolegniasis in cultured fish.

According to Setyawati (20II), marked saprolegniasis disease from the appearance of a mass of hyphae like cotton, white to gray/brown on the body of the infected fish. This opinion is also 
strengthened by Juniati, Amir \& Mukhlis (2015), which states that fish infected with saprolegniasis are characterized by the presence of lumps on the body surface of the fish resembling cotton which causes damage to the skin and fins due to cell necrosis by penetration of hyphae in the epidermis and dermis.

Prevention and treatment efforts that are commonly carried out on fish affected by mycotic diseases are using chemical drugs such as malachite green, formalin, hydrogen peroxida, and so on, but the use of chemicals tends to be not environmentally friendly and some are carcinogenic (Kusdarwati, Murtinintias \& Meles, 2013). Besides, it is feared that the use of chemical drugs will have a further negative impact on organisms. This is by the opinion of Sudarno, Sabrina \& Suprapto, 20I4), which states that the use of chemicals causes negative effects, namely the resistance of microorganisms, the dangers they cause to the surrounding environment, the fish concerned, and the humans who consume them.

To overcome this problem, a safer alternative treatment is needed to control the disease caused by the fungus Saprolegnia sp. Alternatives that can be used include using plants that contain antifungal substances. Besides, these plants are also easy to obtain and easy to use for the prevention and handling of diseases in fish. One of the plants that have the potential to treat disease caused by the fungus Saprolegnia sp. is basil (Ocimum basilicum L). According to Kurniasih (20I4), basil (Ocimum basilicum L) is a plant belonging to the Lamiaceae family/family, with the characteristics of a woody trunk, including a shrub with a height of 30-I50 $\mathrm{cm}$, a rectangular stem, a grooved stem surface, and hair, branched and colored. Green has white flowers and the aroma of this plant is very distinctive. The results of the basil leaf phytochemical screening test conducted by Martiningsih \& Suryanti (2017) using the water distillation method to produce Basil leaf essential oil contains flavonoids, saponins, terpenoids, and tannins. Meanwhile, in research by Kumalasari \& Andiarna (2020) using the maceration method, it was found that 96\% ethanol extract of basil leaves contained flavonoids, alkaloids, saponins, and tannins. Furthermore, Hasan, Raharjo \& Ariyani (2016) added that the basil leaves contain substances as antibacterial and antifungal. Besides, the orientin and vicenin compounds in basil can protect the body's cell structure, while cineole, myrcene, and eugenol function as natural antibiotics and antiinflammatory.

The implementation of research related to the performance of basil leaf extract (Ocimum basilicum L) has been reported by several researchers, including research conducted by Hidayati \& Bahar (2018) who concluded that the ethanol extract of basil leaves (Ocimum basilicum L.) had the effect of inhibiting the growth of Staphylococcus epidermidis bacteria with an effective dose of $850 \mathrm{mg} / \mathrm{mL}$, while the research conducted by Berlian, Aini \& Lestari 2016) The result showed that the antifungal activity of basil leaf extract (Ocimum americanum L.) to inhibit the growth of Fusarium oxysporum Schlecht. is at a concentration of 10\% (w/v). Further research conducted by Treenesia \& Ramadhian (2019), obtained the results of antibacterial activity in the ethanol extract of basil leaves against the growth of S. aureus and S. Typhi bacteria with the highest inhibition zone in S. aureus, namely at a concentration of $100 \%$ with an inhibition zone of $21.75 \mathrm{~mm}$ and S. Typhi at a concentration was $80 \%$ with an inhibition zone was $6.25 \mathrm{~mm}$.

From this description, the authors feel the need to do research using $96 \%$ ethanol extract in basil leaves which aims to determine the effectiveness of basil leaf extract against the fungus Saprolegnia sp. in vitro as the basis for developing the potential of basil extract as an antifungal for treating disease in cultured fish.

\section{RESEARCH METHODS}

\section{Research Design}

This research was conducted from May to June 2019. Basil leaf extraction activities were carried out at the process engineering laboratory, chemical industrial products, department of 
chemical engineering, Sriwijaya University. The antifungal effectiveness test of Saprolegnia $s p$ was carried out at the Mycology Laboratory, Health Analyst Department, Health Polytechnic of the Ministry of Health, Palembang.

This research method was carried out using a completely randomized design (CRD) with 5 treatments and 3 replications which refers to the research of Hasan, et al. 2016). The treatments used are presented in Table I.

Table I. Treatment of basil extract on Saprolegnia $s p$

\begin{tabular}{cl}
\hline Treatment & \multicolumn{1}{c}{ Concentration } \\
\hline P0 & Basil extract with a concentration of $0 \mathrm{ppm}$ \\
\hline PI & Basil extract with a concentration of $20 \mathrm{ppm}$ \\
\hline P2 & Basil extract with a concentration of $40 \mathrm{ppm}$ \\
\hline P3 & Basil extract with a concentration of $60 \mathrm{ppm}$ \\
\hline P4 & Basil extract concentration of $80 \mathrm{ppm}$ \\
\hline
\end{tabular}

\section{Instruments}

The tools used in this research are knife, analytical scale, glass jar, measuring cup, funnel, blender, Erlenmeyer, vortex, aluminum foil, rotary evaporator, spatula, Petri dishes, rubber band, dropper pipette, test tube, test tube rack, hot plate, sieve, beaker glass, cotton buds, autoclave, laminar airflow, refrigerator/fridge, sprayer, bunsen fire, ose needles, tweezers, magnetic stirrer, tissue, cotton, disc paper, micropipettes, calipers, incubators, water bath, vial bottles, TLC plates, digital cameras, and stationery, while the materials used in this study were $12 \mathrm{~kg}$ basil leaves, fungal isolates Saprolegnia sp, fish feed, 96\% ethanol as much as 5 liters, SDA, and alcohol.

Observation of the fungal inhibition zone was carried out by measuring the diameter (minimum diameter and maximum diameter) of the clear zone around the disc paper on the petri dish. The response to microbial growth inhibition refers to Morales, Sierra, Parades, Loyola, Gallardo \& Borquez, 2003), which is very strong antifungal potential if the barrier area is $>20$ $\mathrm{mm}$ in diameter, strong antifungal potential if the barrier area is $10-20 \mathrm{~mm}$ in diameter, has moderate antifungal potential if the barrier area is $5-10 \mathrm{~mm}$ in diameter and has weak antifungal potential if the barrier area is $<5 \mathrm{~mm}$.

\section{Procedures}

\section{Making Basil Extraction (Ocimum sanctum L)}

$12 \mathrm{~kg}$ of fresh basil washed clean then cut into small pieces and then dried in indirect sunlight for 7 days until dry and weighed, then $1.2 \mathrm{~kg}$ of dry basil is obtained, dried basil then mashed using a blender until obtained. dry powder (simplicia) of basil. The simplicia of basil is extracted by immersion (maceration) using 5 liters of ethanol $96 \%$ as much as 5 liters. Simplicia basil used as much as $1.2 \mathrm{~kg}$ then put into 6 beaker glass to do soaking, then add $96 \%$ ethanol which has been distilled until submerged, then close the beaker glass tightly and store for 3 days in a dark place and protected from light. After 3 days the solution was filtered with a Whatman filter vacuum pump No. 42. Then the last step was to do the evaporation using a Rotary Evaporation tool. Then prepare a complete set of vacuum distillation then add the basil maserate from half the capacity of the distillation flask (can be added). Heat a rice cooker that has been filled with water then let the vacuum distillation process run then stop the distillation if there is no more ethanol dripping so that you get a thick basil extract. The thick evaporated extract is stored in the freezer (Widyastuti, 2012). The stages of making a complete basil leaf extract are presented in Figure I. 
Fresh Basil Leaves $12 \mathrm{~kg}$

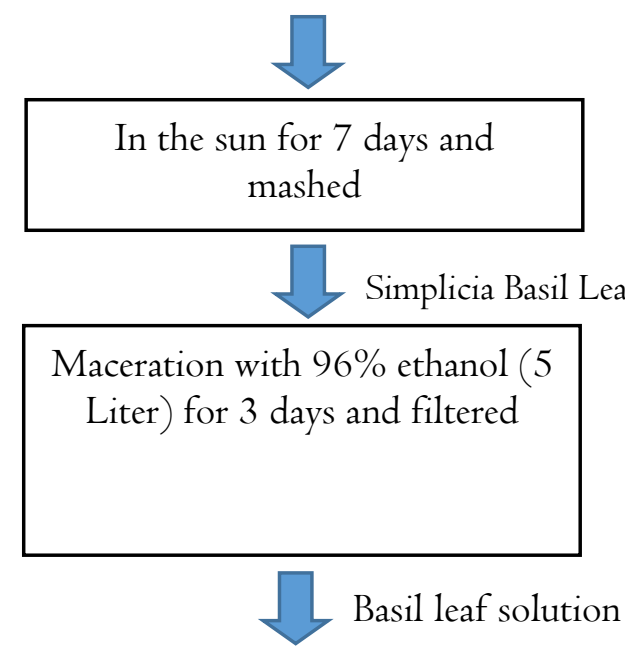

$$
\begin{array}{r}
\begin{array}{r}
\text { Evaporation }+ \text { Distillation } \\
\mathrm{T}=80^{\circ} \mathrm{C}
\end{array} \\
\square
\end{array}
$$

200 grams of basil extract

Figure I. Basil extraction process flow

\section{Antifungal Effectiveness Test}

a. Preparing Media

Making dextrose sabouraud media so that $(+)$ refers to Tanjung (2013), namely weighing the sabouraud dextrose agar as much as 65 grams (composition: I0 grams of mycological peptone, 40 grams of dextrose, I5 grams of agar), then dissolved in I liter of aqua dest. Sterilize into the autoclave for $\mathrm{I} 5$ minutes with a temperature of $\pm \mathrm{I} 2 \mathrm{I}^{0} \mathrm{C}$, then cooled until lukewarm. Add I gram of chloramphenicol antibiotic, stir until homogeneous then pour into a petri dish as much as I5-20 cc. Let it cool and freeze.

b. Mushroom Rejuvenation

Rejuvenation of Saprolegnia sp as much as I ose and inoculated into SDA oblique aseptically by placing an oce needle containing the fungus on the base of the agar slope and pulling it with a zigzag motion, then incubating using an incubator at a temperature of $30^{\circ} \mathrm{C}$ for 24 hours (Lay, I994).

\section{c. Antifungal Sensitivity Test}

The antifungal sensitivity test of basil extract on the fungus Saprolegnia $s p$ is to determine the level of sensitivity or sensitivity of mushrooms to basil extract using various concentrations, namely $20 \mathrm{ppm}, 40 \mathrm{ppm}, 60 \mathrm{ppm}$, and $80 \mathrm{ppm}$. and repeated 3 times ignoring the research (Lingga, Rustikawati \& Burwono, 2012). The sensitivity test was carried out using the diffusion method so that $0.1 \mathrm{ml}$ of the mushroom suspension was spread over each solidified SDA using L glass. Disc paper with a diameter of $6 \mathrm{~mm}$ was dripped with $20 \mu \mathrm{l}$ with various concentrations using a micropipette. After that, it is placed on the agar medium which has been spread by the fungus Saprolegnia $s p$ and labeled. Furthermore, the agar medium was incubated for 24 hours at a temperature of $30^{\circ} \mathrm{C}$. 
Observed and recorded by measuring the clear zone around the disc paper using a ruler and calculating the average value of the diameter of the formed inhibition zone. The antifungal sensitivity test was stated to be active by looking at the inhibition zone in the clear area around the disc paper which indicated a growth inhibitor.

\section{Data Analysis}

The research data were analyzed using analysis of variance (ANOVA). If the analysis of variance (ANOVA) results show the value of Fcount $>$ Ftable on $\alpha=0.05$ and 0.0 I then it will be further tested. For the KK value (Coefficient of Diversity) I-5\%, it will be further tested using $\mathrm{BNJ}$ (Honest Real Difference), if the KK value is 5-10\% then it will be further tested using BNT (Least Real Difference) and if the KK value is $>10 \%$ then it will be further tested using Duncan (Hanafiah, 2010), while the data on the results of the effectiveness test were discussed descriptively.

\section{RESULTS}

The total amount of basil extract using 96\% ethanol with the maceration method yields 200 grams of basil extract with a yield of $16.67 \%$. The resulting basil extract is served in Figure 2.

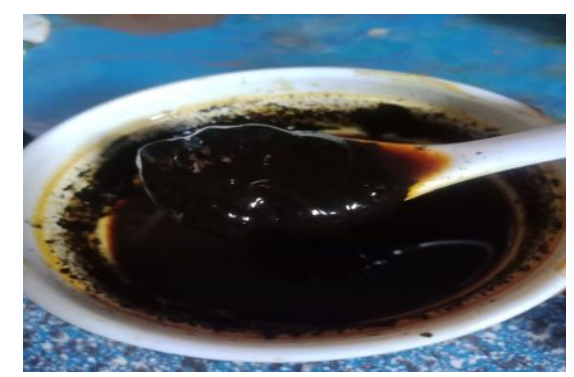

Figure 2. Basil extract (Ocimum sanctum L)

The results of testing the effectiveness of basil extract against Saprolegnia sp. were obtained by measuring the resulting inhibition zone diameter as presented in Table 2 and Figure 3.

Table 2. Inhibition zone diameter of basil extract against Saprolegnia sp.

\begin{tabular}{|c|c|c|}
\hline Treatment & $\begin{array}{c}\text { The diameter of the inhibition zone } \\
\text { of basil extract (mm) }\end{array}$ & Inhibition Ability \\
\hline P0 (control) & $\mathrm{O}^{\mathrm{a}}$ & - \\
\hline PI (20 ppm) & II.33 b & Strong \\
\hline P2 (40 ppm) & $18.30^{\mathrm{d}}$ & Strong \\
\hline P3 (60 ppm) & $22^{\mathrm{e}}$ & Very strong \\
\hline $\mathrm{P} 4(80 \mathrm{ppm})$ & $15^{\mathrm{c}}$ & Strong \\
\hline \multicolumn{3}{|c|}{ (Morales, et al, 2003) } \\
\hline & $\begin{array}{l}\text { The diameter of the } \\
\text { inhibition zone on th }\end{array}$ & \\
\hline
\end{tabular}

Figure 3. Inhibition zone diameter of basil extract against Saprolegnia sp.

dol10.31932/jpbio.v6iI.853 Sasmita et al @iurnaljpbio@gmail.com




\section{DISCUSSION}

Based on Table I above, it was found that $20 \mathrm{ppm}$ treatment resulted in an inhibition zone diameter of II.33 mm, $40 \mathrm{ppm}$ treatment resulted in an inhibition zone diameter of $18.33 \mathrm{~mm}, 60$ ppm treatment showed an inhibition zone diameter of $22 \mathrm{~mm}$ and treatment of 80 ppm resulted in an inhibition zone diameter of $15 \mathrm{~mm}$. The concentration of basil extract in each treatment resulted in a different diameter of the inhibition zone. This is by the opinion of Martiningsih (2017) which states that the diameter of the inhibition zone formed in each treatment is different, this is because the growth of fungal isolates in the media is influenced by several factors, including the concentration of antimicrobial substances, the number of microorganisms, the presence of organic matter, temperature, degree of acidity. $(\mathrm{pH})$ and species of organisms.

Refers to Figure 2, it can be seen that the diameter of the inhibition zone is a clear area around the Paper Disc that is not overgrown with fungus. Based on Duncan's continued test, the concentration of basil extract was significantly different at concentrations of $0 \mathrm{ppm}$ and $20 \mathrm{ppm}$ with different notations, namely $\mathrm{a}$ and $\mathrm{b}$, this indicates that the concentration of the basil extract had a different effect on the growth of the fungus Saprolegnia sp. It is suspected that the lower the concentration of basil extract, the smaller the diameter of the clear zone formed around the disc paper. This is by the opinion of Fadilah (2018), which states that the smaller the concentration of the extract, the less the amount of active substance dissolved in the extract so that the ability to inhibit fungal growth is lower. Conversely, the higher the concentration, the more active substances that function as anti-fungi, so that the ability to inhibit fungal growth is greater.

The concentrations of $40 \mathrm{ppm}$ and $60 \mathrm{ppm}$ in Duncan's continued test showed significantly different results because they had different notations, namely $d$, and e. The concentration of 60 ppm resulted in the highest clear zone diameter of $22 \mathrm{~mm}$ compared to the concentration of 40 $\mathrm{ppm}$ which was $18.33 \mathrm{~mm}$, it is suspected that the increase in the concentration of basil extract was due to the content of alkaloids, tannins, saponins, flavonoids and phenols which functioned. as an antifungal so that it can increase its ability to inhibit fungal growth (antifungal). This is by the opinion of Morales et al. (2003) which states that, if the diameter of the resistance area is $20 \mathrm{~mm}$ or more, it means that it has a very strong anti-fungal activity. While the concentration of $80 \mathrm{ppm}$ experienced a decrease in the inhibition zone diameter in the fungus Saprolegnia sp. This is presumably because the basil extract was too thick so it was difficult to diffuse maximally in the fungus Saprolegnia $s p$.

Waluyo (2008) said that the diffusion method is often used to determine the sensitivity of fungi. The principle of this method is the inhibition of the growth of microorganisms in the presence of an inhibition zone in the form of a clear area around the paper disc containing an antifungal agent. The diameter of the zone of growth inhibition indicates the sensitivity of the fungus to antifungal substances, then it is said that the wider the diameter of the inhibition zone formed, the more sensitive the fungus is. Other than that, Dani, Nurtjahja \& Zuhra (2015) also added that too high a concentration of the extract could result in saturation, causing the active compounds contained to be unable to dissolve completely.

\section{CONCLUSION}

Based on the results of the research that has been done, it is concluded that the extract of basil (Ocimum santcum L) is proven to inhibit the growth of the fungus Saprolegnia sp in vitro. The ethanol extract of basil with a concentration of $60 \mathrm{ppm}$ had the largest inhibition zone diameter of $22 \mathrm{~mm}$ in inhibiting the growth of the fungus Saprolegnia $s p$ in vitro compared to the concentrations of other ethanol extracts of basil. The limitation of this study is that the application of basil leaf extracts to Saprolegnia sp. Was carried out in a laboratory. For this reason, it is 
necessary to carry out further research with the direct application of basil leaf extract to various types of cultivated fish commodities.

\section{REFERENCES}

Berlian, Z., Aini, F., \& Lestari, W. (2016). Anti-fungal activity of basil leaf extract (Ocimum americanum L.) against fusarium oxysporum schlecht. Journal of Biota, 2(I), 99-105. Retrieved from file: /// C: /Users/Surface/Downloads/537-Article\%20Text-II47-I-I020160429.pdf

Dani, I.W., Nurtjahja, K., \& Zuhra, C.F. (2012). Inhibition of growth of aspergillus flavus and fusarium miniliforme by salam (Eugenia polyantha) and turmeric (Curcuma domestica) Extracts. Journal of Biological Sciences, I (I), 7-I3. Retrieved from https://www.neliti.com/id/publications/221075/penghambat-pertumbuh-aspergillus-

flavus-dan-fusarium-moniliforme-oleh-ekstra

Fadilah, L.L. (2018). The use of kedondong leaf extract (Spondias pinnata) to inhibit the growth of mushroom mycelia saprolegnia sp. in vitro. Bio Lantern Periodic Scientific Biology, 7(I), 28-32.

Retrieved

from

https://jurnalmahasiswa.unesa.ac.id/index.php/lenterabio/article/view/28339/25920

Hanafiah, K.A. (2010). Experimental design: theory and application. Edition 3. Raja Grafindo Persada. Jakarta. 274hlm.

Hasan, H., Raharjo, E.I., \& Ariyani, D.D. (2016). Effect of basil leaf extract (Ocimum basilicum L) on Hatching power of african catfish (Clarias gariepinus) infected by Saprolegnia Sp. Jurnal Ruaya, Journal of Research and Studies in Fisheries and Marine Sciences, 4(I), I8-23. Retrieved from http://dx.doi.org/I0.29406/rya.v4iI,688

Hidayati, A.N.A., \& Bahar, Y. (2018). Effects of basil leaves (Ocimum Basilicum L.) on Staphylococcus Epidermidis Bacteria. Saintek, 5(I), 55-60. Retrieved from http://dx.doi.org/I0.30595/sainteks.vI5iI.6I79

Juniati, K., Amir, S., \& Mukhlis, A. (2015). The effect of zoospora concentration on the prevalence of Saprolegnia sp in tilapia oreochromis niloticus. Journal of Fisheries Unram, 7, I-8. Retrieved from file: /// C: /Users/Surface/Downloads/57-Article\%20Text-227-II0-201805I9.pdf

Kumalasari, M.L.F, \& Andiarna, F. (2020). Phytochemical test of the ethanol extract of basil leaves (Ocimum Basilicum L). Indonesian Journal for Health Sciences, 4(I), 39-44. Retrieved from http://dx.doi.org/I0.24269 / ijhs.v4iI.2279

Kurniasih. (2014). Powerful benefits of basil. New Library Press. Yogyakarta.

Kusdarwati, R., Murtinintias, P., \& Meles, D.K. (2013). Antifungal activity test of betel leaf extract (Piper Betle L) against Saprolegnia sp by in vitro. Fisheries and Marine Scientific Journal, 5 (I), I5-2I. Retrieved from http://dx.doi.org/I0.20473 / jipk.v5iI.II420

Lay, B.W. (1994). Microbial analysis in the laboratory. Raja Grafindo Persada. Jakarta.

Lingga, N.M., Rustikawati, I., \& Burwono, D.I. (20I2). Effectiveness of kecombrang (Nicolaia speciosa Horan) Extract to prevent attacks by Saprolegnia sp at sangkuriang Lele. Journal of Fisheries and Marine Affairs, 3(4), 75-80. Retrieved from http://jurnal.unpad.ac.id/jpk/article/view/2547

Martiningsih, N.W., \& Suryanti, I.A.P. (2017). Phytochemical screening and anti-fungal activity of basil leaf essential oil (Ocimum sp.). Proceedings National Seminar on Innovative Research, 63I-636. Retrieved from http://digilib.mercubuana.ac.id/manager/ t!@file _artikel_abstrak / Isi_Artikel_42458I384246.pdf

Morales, G., Sierra, P., Parades, A., Loyola, L., Gallardo \& Borquez. (2003). Secondary metabolites from four medicinal plants from northern Chile: Antimicrobial activity and biotoxicity 
against artemia salina. Journal of the Chilean Chemical Society, 48, I3-I8. Retrieved from http://dx.doi.org/I0.4067 / S0717-97072003000200002

Setyawati, S.M. (20II). Histopathology of achlya heterosexualis in body tissue of catfish (Clarias batrachus L.). Phenomenon: Journal of Mathematics and Natural Sciences Education, I(2). Retrieved from http://dx.doi.org/I0.2I 580\%20/\%20phen.20I I.I.2.432

Sudarno, S., Sabrina, T.I., \& Suprapto, H. (20I4). Antifungal activity test of basil leaf juice (Ocimum sanctum L.) against aspergilllus terreus in vitro. Fisheries and Marine Scientific Journal, 6(2), I7I-I78. Retrieved from http://dx.doi.org/I0.20473/jipk.v6i2.I I305

Tanjung, H. (2013). Effect of basil extract (Ocimum sanctum L) on the growth of candida albicans fungi. Final report. Department of Health Analyst, Palembang Health Polytechnic.

Treenesia, A., \& Ramadhian, M.R. (2019). Comparison of the effects of ethanol extract of basil leaves (Ocimum sanctum L.) on In vitro growth inhibition of staphylococcus aureus and salmonella typhi. Journal of Agromedicine, 6(I), I20-I24. Retrieved from https://juke.kedpes.unila.ac.id/index.php/agro/article/view/2262

Waluyo, L. (2008). Basic techniques and methods in microbiology. Poor. UMM Press.

Widyastuti, H.S.C. (2012). Herbal screening for streptococcosis and motile aeromonad septicemia (mas) in vitro. Essay. IPB Bogor. Retrieved from https://repository.ipb.ac.id/handle/I23456789/55626 